\title{
Mechanism of protein tyrosine phosphatase 1B-mediated inhibition of leptin signalling
}

\author{
I K Lund ${ }^{1}$, J A Hansen ${ }^{1}$, H S Andersen², N P H Møller ${ }^{1}$ and N Billestrup ${ }^{1,3}$ \\ ${ }^{1}$ Signal Transduction, Novo Nordisk A/S, DK-2880 Bagsværd, Denmark \\ ${ }^{2}$ MedChem Research II, Novo Nordisk A/S, DK-2760 Måløv, Denmark \\ ${ }^{3}$ Steno Diabetes Center, Niels Steensens Vej 6, DK-2820 Gentofte, Denmark
}

(Requests for offprints should be addressed to N Billestrup; Email: nbil@steno.dk)

\begin{abstract}
Upon leptin binding, the leptin receptor is activated, leading to stimulation of the JAK/STAT signal transduction cascade. The transient character of the tyrosine phosphorylation of JAK2 and STAT3 suggests the involvement of protein tyrosine phosphatases (PTPs) as negative regulators of this signalling pathway. Specifically, recent evidence has suggested that PTP1B might be a key regulator of leptin signalling, based on the resistance to diet-induced obesity and increased leptin signalling observed in PTP1B-deficient mice. The present study was undertaken to investigate the mechanism by which PTP1B mediates the cessation of the leptin signal transduction. Leptin-induced activation of a STAT3 responsive reporter was dose-dependently inhibited by co-transfection with PTP1B. No inhibition was observed when a catalytically inactive mutant of PTP1B was used or when other PTPs were co-transfected. PTP1B was able to dephosphorylate activated JAK2 and STAT3 in vitro, whereas either no or a minimal effect was observed with cluster of differentiation 45 (CD45), PTP $\alpha$ and leukocyte antigen-related (LAR). By utilisation of a selective PTP1B inhibitor, the leptin-induced STAT3 activation was enhanced in cells. In conclusion, these results suggested that the negative regulatory role of PTP1B on leptin signalling is mediated through a direct and selective dephosphorylation of the two signalling molecules, JAK2 and STAT3.
\end{abstract}

Journal of Molecular Endocrinology (2005) 34, 339-351

\section{Introduction}

Leptin, the $16 \mathrm{kDa}$ protein product of the obese gene (Zhang et al. 1994), is an adipocyte-derived hormone, secreted in proportion to the total body fat mass (Banks 2003). The primary site of leptin action is the hypothalamus, through which it exerts its key regulatory role by controlling the overall energy homeostasis, i.e. induction of reduced food intake and promotion of weight loss (Ahima \& Flier 2000, Korner \& Aronne 2003). Defective leptin signalling due to either leptin deficiency or dysfunctional leptin receptors leads to early onset of severe obesity in both humans and rodents (Clement et al. 1998, Ahima \& Flier 2000). In human obesity and type 2 diabetes, circulating levels of leptin are usually elevated and consequently accompanied by a reduced sensitivity to leptin (often referred to as leptin resistance) (El Haschimi et al. 2000). At present, the exact molecular mechanism eliciting this physiological insensitivity has not been characterised. However, the existence of impaired leptin transport across the blood-brain barrier and/or the deregulation of the activity of proteins participating in the negative feedback mechanism on leptin signalling seem to constitute important aspects for the presence of leptin resistance (Bjørbæk et al. 1999, El Haschimi et al. 2000, Banks 2003).
Structurally, the leptin receptor belongs to the class I cytokine receptor family (Tartaglia et al. 1995, Tartaglia 1997), for which a common feature is the highly conserved Box 1 and Box 2 motifs, positioned in the cytoplasmic region and known to be of importance for association and activation of signalling molecules (Ihle \& Kerr 1995, Kloek et al. 2002). Upon leptin stimulation, the ligand-induced conformational changes of the leptin-bound receptor dimers lead to recruitment of JAK2 proteins to the cytoplasmic domain of the receptor (Tartaglia 1997, Ahima \& Flier 2000, Sweeney 2002). Subsequent tyrosine phosphorylation and activation of JAK2 and the leptin receptor result in the creation of docking sites for signalling molecules, such as the STAT3 proteins. In particular, the phosphorylated STAT3 proteins dimerise, translocate into the nucleus and regulate expression of target genes through DNA binding (Ahima \& Flier 2000, Levy \& Darnell 2002).

The mechanisms controlling and terminating the leptin signal transduction seem more elusive but are believed to include (i) internalisation and degradation of the leptin receptor-ligand complex (possibly via the ubiquitin-proteaosome pathway) (Haspel et al. 1996), (ii) feedback inhibition by negative regulators such as the cytosolic suppressors of cytokine signalling (SOCS) (Bjørbæk et al. 1999, Gadina et al. 2001) and the nuclear 
protein inhibitor of activated STAT (Gadina et al. 2001) and (iii) dephosphorylation and inactivation of signalling proteins mediated by protein tyrosine phosphatases (PTPs) (Haspel et al. 1996, You et al. 1999, Kaszubska et al. 2002, Yamada et al. 2002, Andersen et al. 2004).

The transient character of the leptin-induced tyrosine phosphorylation of JAK and STAT proteins suggests the presence of PTPs, although little is known about the role of these enzymes in the cessation of the leptin signalling pathway. Two elegant studies have recently provided evidence for the presence of an increased insulin sensitivity, resistance to diet-induced obesity and increased energy expenditure in PTP1B-deficient mice (Elchebly et al. 1999, Klaman et al. 2000). The increased insulin sensitivity and prolonged tyrosine phosphorylation of the insulin receptor tyrosine kinase (IRTK) in these mice suggest a direct negative regulatory role of PTP1B on the IRTK, and thus on glucose homeostasis; a notion corroborated by the improved glucose tolerance observed in mice deficient in PTP1B and insulin receptor substrate-2 (IRS-2) (Kushner et al. 2004) and in rodents treated with PTP1B antisense oligonucleotides (Rondinone et al. 2002, Zinker et al. 2002, Gum et al. 2003). The resistance to diet-induced obesity and increased energy expenditure, together with a recent study suggesting JAK2 as a substrate of PTP1B (Myers et al. 2001), clearly points to a central role of PTP1B in leptin signalling. In agreement, subsequent studies have illustrated augmented leptin signalling in the two strains of PTP1B knockout mice (Cheng et al. 2002, Zabolotny et al. 2002). Recent reports have additionally provided support for a negative regulatory role of PTP1B in JAK/ STAT-mediated signalling upon induction with various cytokines such as leptin (Kaszubska et al. 2002), prolactin (Aoki \& Matsuda 2000) and growth hormone (Gu et al. 2003).

In order to understand the molecular mechanism behind the action of PTP1B on the signalling molecules transmitting the effects of leptin, we have investigated the role of PTP1B and related PTPs on leptin signalling using (i) a leptin-responsive STAT3-dependent reporter assay, (ii) an in vitro dephosphorylation assay of JAK2 and STAT3 and (iii) a prodrug inhibitor with selectivity for PTP1B applied to cells in which STAT3 DNA binding were measured.

\section{Materials and methods}

\section{Materials}

All cell culture reagents were purchased from GIBCO-BRL Life Technologies (Gaithersburg, MD, USA) and Sigma unless otherwise is noted. Other chemicals were analytic grade from Merck, Darmstadt, Germany. Water was purified in a Millipore purification system (18 Megohm/cm; Millipore Inc., Glostrup,
Denmark). Insulin and leptin were from Novo Nordisk A/S, (Bagsvæerd, Denmark).

\section{Cell culture}

Human embryonic kidney (HEK) 293 cells stably transfected with the human leptin receptor were cultured in RPMI 1640 medium supplemented with $10 \%$ fetal calf serum (FCS), 100 units/ml penicillin and $100 \mu \mathrm{g} / \mathrm{ml}$ streptomycin. Chinese hamster ovary (CHO) cells were cultured in Ham's F-12, supplemented with $10 \%$ FCS and 100 units $/ \mathrm{ml}$ penicillin and $100 \mu \mathrm{g} / \mathrm{ml}$ streptomycin. HEK293 cells and CHO cells were cultured at $37^{\circ} \mathrm{C}$ in a humidified atmosphere containing $5 \% \mathrm{CO}_{2}$ in air. For all leptin stimulations, recombinant leptin was used at a final concentration of $200 \mathrm{ng} / \mathrm{ml}$.

\section{Cloning, expression and purification of recombinant PTPs}

cDNA cloning of the catalytic domains of wild-type (wt) PTP1B, SHP-2, PTP $\alpha$ domain 1 and CD45 domain $1-2$, were performed as described previously (Andersen et al. 2000, Iversen et al. 2001). The PTP LAR expression vector was a kind gift from M Streuli, Dana-Farber Cancer Institute and Harvard Medical School, Boston, MA, USA. All constructs were inserted into pGEX-5X expression vectors (Amersham Pharmacia Biotech). All coding sequences were confirmed by DNA sequencing. Expression and purification of the glutathione $S$-transferase (GST) fusion proteins were performed as described previously (Iversen et al. 2001, Lund et al. 2004).

\section{Transient transfection assays, $\beta$-galactosidase and chloramphenicol acetyl transferase (CAT) assays}

CHO cells were seeded $\left(4 \times 10^{5}\right)$ in $60 \mathrm{~mm}$ tissue culture dishes (Nunc, Roskilde, Denmark) in Ham's F-12 medium supplemented with $10 \%$ FCS, 100 units $/ \mathrm{ml}$ penicillin and $100 \mu \mathrm{g} / \mathrm{ml}$ streptomycin at $37^{\circ} \mathrm{C}$. Twenty-four hours prior to transfection, cells were washed twice and incubated in $3 \mathrm{ml}$ serum-free GC3 medium (1:1 mixture of Dulbecco's modified Eagles' medium and Ham's F-12, supplemented with $10 \mu \mathrm{g} / \mathrm{ml}$ transferrin, $160 \mathrm{mU} / \mathrm{ml}$ insulin, $2 \mathrm{mM} \mathrm{L}$-glutamine, $2 \mathrm{mM}$ non-essential amino acids, $100 \mathrm{units} / \mathrm{ml}$ penicillin and $100 \mu \mathrm{g} / \mathrm{ml}$ streptomycin). Cells were transiently transfected by the calcium phosphate precipitation method as described previously (Chen \& Okayama 1987) with the following amounts for each expression vector (per dish) in Opti-MEM medium: $3 \mu \mathrm{g} \mathrm{SV} 40 / \beta$ galactosidase (pCH110 plasmid from Pharmacia Biotech Inc.), $1.5 \mu \mathrm{g}$ Insulin promoter gamma-like element (Ins-GLE) CAT reporter construct (Galsgaard et al. 1996), $1.5 \mu \mathrm{g}$ leptin receptor and $0 \cdot 25-2 \cdot 0 \mu \mathrm{g}$ PTP 
(expression plasmids containing cDNAs encoding the various PTP forms have been inserted into the pcDNA $3 \cdot 1^{+}$vector from Invitrogen). As control, the empty pcDNA $3 \cdot 1^{+}$vector was used. Cells were incubated for $4 \mathrm{~h}$, washed and subsequently cultured in serum-free GC3 medium in the absence or presence of $200 \mathrm{ng} / \mathrm{ml}$ leptin. After $24 \mathrm{~h}$, cells were harvested and the $\beta$-galactosidase activity of each cellular extract was measured as follows: $10 \mu \mathrm{l}$ cellular extract was mixed with $1 \mathrm{ml} \beta$-gal buffer $\left(60 \mathrm{mM} \mathrm{Na}_{2} \mathrm{HPO}_{4}, 40 \mathrm{mM} \mathrm{NaH}_{2} \mathrm{PO}_{4}\right.$, $10 \mathrm{mM} \mathrm{KCl}$ and $1 \mathrm{mM} \quad \mathrm{MgSO}_{4}$ ) supplemented with $\beta$-mercaptoethanol and $\mathrm{O}$-nitrophenyl- $\beta$-D-galactopyranoside. The reaction mixture was incubated at $37^{\circ} \mathrm{C}$ for $2 \mathrm{~h}$ and absorbance was measured at $420 \mathrm{~nm}$, and used for normalisation of transfection efficiency (i.e. internal control) before determination of CAT activity. The CAT assay was performed as previously described (Galsgaard et al. 1996). The concentration of leptin used in this assay $(200 \mathrm{ng} / \mathrm{ml})$ was found in dose-response experiments to give maximal stimulation of transcription. All experiments were performed in duplicate and repeated at least three times.

\section{Generation of phosphorylated GST-JAK2 fusion proteins}

The cDNA encoding the tyrosine kinase domain of JAK2 was amplified by PCR from a plasmid containing the cDNA encoding the full-length JAK2. The following primers were used: 5 '-oligonucleotide sense primer with a BamHI restriction enzyme site at its $5^{\prime}$-end; $5^{\prime}$-atagg gatccCGAAACCACAGCCACTT- $3^{\prime}$ and an antisense $3^{\prime}$-oligonucleotide primer with an XhoI restriction enzyme site at its $5^{\prime}$-end; 5'-ccgctcgagCTGGATGA TTTTGTT-3'. The PCR product was digested with BamHI and XhoI and the BamHI/XhoI fragment encoding the JAK2 amino acid residues (850-1132) was ligated into the GST fusion vector pGEX-5X-3 (Pharmacia Biotech Inc.). The coding sequence of the resulting plasmid was confirmed by DNA sequencing. Induction and affinity purification of the GST-JAK2 fusion proteins was performed as recommended by the manufacturer (Pharmacia Biotech Inc.) using the Epicurian coli TKX1 strain that harbours a plasmid encoding an inducible tyrosine kinase (elk) gene as recommended by the manufacturer (Stratagene, La Jolla, CA, USA).

\section{Dephosphorylation of pTyr-GST-JAK2 and PTyr-STAT3 proteins in vitro}

Preparations of pTyr-GST-JAK2 fusion proteins (400 ng protein) or nuclear extracts from HEK293 cells containing pTyr-STAT3 proteins ( $5 \mu \mathrm{g}$ protein) were incubated with different recombinant PTPs in assay buffer $(20 \mathrm{mM}$ Hepes, $50 \mathrm{mM} \mathrm{NaCl}$ and $1 \mathrm{mM}$ EDTA, $\mathrm{pH}$ 6.5; final volume of $16 \mu \mathrm{l})$ for the indicated time-periods $(0 \cdot 5$ $20 \mathrm{~min})$ at $25^{\circ} \mathrm{C}$. The reaction was stopped by the addition of $4 \mu \mathrm{l} 5 \times$ SDS sample buffer, followed by heating $\left(10 \mathrm{~min}\right.$ at $\left.90{ }^{\circ} \mathrm{C}\right)$. The amount of recombinant PTP used in the assay was normalised according to the catalytic PTP activity, determined by hydrolysis of $p$-nitrophenyl phosphate ( $p$ NPP; Sigma) (see below).

\section{Western blot analysis}

For detection of PTP-induced dephosphorylation of pTyr-JAK2 and pTyr-STAT3, the proteins were separated by use of the Novex electrophoresis system (Invitrogen), blotted onto PVDF membranes (Invitrogen) and visualised by the ECL plus detection system (Amersham Pharmacia Biotech) as previously described (Richter et al. 2003). The primary antibodies used were anti-JAK2 pTyr $^{1007}$ pTyr $^{1008}$ antibody (Biosource International, Camarillo, CA, USA) or anti-PTyr (4 G10; Upstate Biotechnology Inc., Lake Placid, NY, USA), and anti-pTyr 705 STAT-3 antibody (Cell Signaling Technology Inc., Beverly, MA, USA), both diluted in 1:1000 in TBST $(50 \mathrm{mM}$ Tris/HCl, $\mathrm{pH} 7 \cdot 4$, $150 \mathrm{mM} \mathrm{NaCl}$ and $0 \cdot 1 \%$ Tween 20 ) with $0 \cdot 25 \%$ bovine serum albumin. Goat anti-rabbit horseradish peroxidase-conjugated antibody (Amersham Pharmacia Biotech) diluted 1:5000 was used as secondary antibody. For the control of equal amounts of protein, the pTyr blots were stripped and re-probed with specific antibodies, i.e. anti-STAT3 antibody (Santa Cruz Biotechnology, Santa Cruz, CA, USA; diluted 1:500) and anti-JAK2 (Upstate Biotechnology; diluted 1:5000), as previously described (Stofega et al. 2000).

\section{Measurement of PTP1B catalysed hydrolysis of pNPP}

The phosphatase activity was assayed using $p$ NPP as substrate and carried out essentially as described previously (Iversen et al. 2001, Lund et al. 2004). The assay buffer ( $\mathrm{pH} 7 \cdot 4$ ), consisting of $50 \mathrm{mM} \mathrm{3,3-}$ dimethylglutarate, $1 \mathrm{mM}$ EDTA, $5 \mathrm{mM}$ glutathione and $0.5 \%$ FCS (not heat-inactivated) was adjusted to an ionic strength of $0 \cdot 15 \mathrm{M}$ by the addition of $\mathrm{NaCl}$. In brief, appropriately diluted inhibitors (undiluted and $50 \mu \mathrm{M}$ compound) were added to the reaction mixture containing 0 or $2.5 \mathrm{mM} p \mathrm{NPP}$ (final assay concentration, total volume of $100 \mu \mathrm{l})$. The reaction was initiated by the addition of the enzyme (i.e. recombinant PTP1B) and allowed to proceed for 5 min before the inhibitor was added and the time was recorded, i.e. continued incubation for 5-60 min at $37^{\circ} \mathrm{C}$. The reaction was stopped by the addition of $20 \mu \mathrm{l} 0.5 \mathrm{M} \mathrm{NaOH}$ in $50 \%$ ethanol. The enzyme activity was determined by measuring the absorbance at $405 \mathrm{~nm}$ using a Spectra MAX384 microplate spectrophotometer (Molecular 
Devices Inc., Sunnyvale, CA, USA) with appropriate corrections for absorbance of substrate, compounds and non-enzymatic hydrolysis of substrate. The reported standard deviation values were calculated from at least four independent experiments.

\section{Statistical analyses}

Data are presented as means \pm S.D. Statistical analyses were performed using GraphPad Prism software. Statistical significance was tested with two-tailed unpaired $t$-test. Differences were considered significant if $P<0 \cdot 05$.

\section{Nuclear extracts and electrophoretic mobility shift assay (EMSA)}

The HEK293 cells were seeded in $10 \mathrm{~cm}$ tissue culture dishes (Nunc) in RPMI 1640 medium supplemented with $10 \%$ FCS, 100 units $/ \mathrm{ml}$ penicillin and $100 \mu \mathrm{g} / \mathrm{ml}$ streptomycin at $37^{\circ} \mathrm{C}$. After an overnight starvation in RPMI 1640 supplemented with $0.5 \%$ FCS, 100 units $/ \mathrm{ml}$ penicillin and $100 \mu \mathrm{g} / \mathrm{ml}$ streptomycin, the cells were preincubated with $50 \mu \mathrm{M}$ 2-(ethoxyoxalylamino)-4,5,6,7-tetrahydro-thieno[2,3-c]pyridine-3-carboxylic acid ethyl ester (trifluoroacetate) (compound 2) for $30 \mathrm{~min}$, followed by the addition of $200 \mathrm{ng} / \mathrm{ml}$ leptin. After incubation for 0,10 or $30 \mathrm{~min}$ at $37^{\circ} \mathrm{C}$, the culture dishes were placed on ice, and the cells were washed twice with ice-cold PBS and lysed in buffer A $(20 \mathrm{mM}$ Hepes, pH 7.9, $10 \mathrm{mM} \mathrm{KCl,} 1 \mathrm{mM} \mathrm{MgCl}_{2}, 1 \mathrm{mM}$ EDTA, $1 \mathrm{mM}$ dithiothreitol, $0.5 \mathrm{mM}$ 4-(2-aminoethyl)benzene sulfonyl fluoride, $1 \mathrm{mM}$ sodium orthovanadate, $1 \mu \mathrm{g} / \mathrm{ml}$ aprotinin, $1 \mu \mathrm{g} / \mathrm{ml}$ leupeptin and $20 \%$ glycerol) containing $0 \cdot 5 \%$ triton X-100. After 5 min of incubation on ice, the nuclei were collected by centrifugation at $2500 \boldsymbol{g}$ for $7 \mathrm{~min}$ at $4{ }^{\circ} \mathrm{C}$, resuspended in 5 volumes of a hypertonic buffer (buffer A containing $400 \mathrm{mM} \mathrm{NaCl}$ ), and incubated on a rocking platform for $30 \mathrm{~min}$ at $4{ }^{\circ} \mathrm{C}$. The supernatant was collected after centrifugation at $20000 \boldsymbol{g}$ for $30 \mathrm{~min}$ at $4{ }^{\circ} \mathrm{C}$. The double-stranded m67 serum inducible element (SIE) oligonucleotide $\left(5^{\prime}\right.$-agctTCATTTCGGGTAAATCGGTA-3') was ${ }^{32} \mathrm{P}$ labelled in a fill-in reaction using $\left[\alpha^{-32} \mathrm{P}\right]$-dCTP and DNA polymerase (Klenow fragment). An approximately 20 fmol probe was used per reaction with $10 \mu \mathrm{g}$ nuclear extract in EMSA buffer $(100 \mathrm{mM}$ Hepes, pH 7.9, $10 \mathrm{mM} \mathrm{NaCl}, 1 \mathrm{mM} \mathrm{MgCl}_{2}, 1 \mathrm{mM}$ EDTA and $10 \%$ (v/v) glycerol) containing $0 \cdot 1 \mu \mathrm{g} / \mu \mathrm{l}$ double-stranded poly dI/dC (polydeoxyinosinic-deoxycytidylic acid; Amersham Pharmacia). The EMSA reactions were preincubated for $30 \mathrm{~min}$ at $30{ }^{\circ} \mathrm{C}$ prior to separation on a $5 \%$ polyacrylamide gel containing $2 \%$ glycerol and $0 \cdot 25 \%$ TBE $(25 \mathrm{mM}$ Tris/HCl, $25 \mathrm{mM}$ boric acid and $0.25 \mathrm{mM}$ EDTA, pH 7.9). The gel was dried and visualised by autoradiography and quantified by Image
Quant analysis (Molecular Dynamics, Sunnyvale, CA, USA). The specificity of the complex was demonstrated by competition with increasing amounts of either cold specific oligonucleotide m67 SIE (see above) or non-specific oligonucleotide $(\alpha \mathrm{CG}$; i.e. 5'-GATCAAAT TGACGTCATGGTAAAA-3') (Galsgaard et al. 1996) (not shown). In addition, the presence of STAT3 in this complex was confirmed upon preincubation of the nuclear extracts with anti-STAT3 antibody, which resulted in a super-shift band (not shown).

\section{Compound synthesis}

The preparation of 2-(oxalylamino)-4,5,6,7-tetrahydrothieno[2,3-c]pyridine-3-carboxylic acid (compound 1) and of its prodrug ester, compound 2, have been described previously (Iversen et al. 2000, Andersen et al. 2002).

\section{Results}

The precise molecular events involved in the regulation of transmission, duration and termination of leptin signal transduction remain to be fully elucidated. Compelling evidence suggests JAK2 and STAT3 as important signalling molecules in the mediation of leptin-induced effects in the central nervous system and the peripheral tissues (Banks 2003, Cui et al. 2004). Results from studies of PTP1B-deficient mice and cell lines derived therefrom suggest a key role of PTP1B in the control of leptin and insulin signalling (Elchebly et al. 1999, Klaman et al. 2000, Cheng et al. 2002, Zabolotny et al. 2002), which is further supported by studies pointing towards JAK2 as a bona fide substrate of this PTP (Myers et al. 2001). We therefore set out to investigate if PTP1B mediates the cessation of the leptin signal transduction by direct targeting of signalling molecules such as JAK2 and STAT3.

\section{Selective and dose-dependent inhibition of leptin-induced transcription by PTP1B}

The effect of PTP1B on leptin-induced STAT3dependent transcription was analysed using transient transfection of CHO cells with the STAT3-responsive proximal part of the insulin promoter linked to a CAT reporter. A 6 -fold stimulation of leptin-induced transcription was observed in control cells (Fig. 1). Co-transfection with either wt PTP1B or a truncated form of PTP1B $\left(\mathrm{PTP}_{1 B_{1-321}}\right.$ ) (Tonks et al. 1988) resulted in a significant and dose-dependent suppression of leptin-induced transcription. PTP1B $1-321$ seemed slightly more potent in inhibiting reporter activity compared with wt PTP1B, in that only half the amount of PTP construct was necessary to obtain complete inhibition $(1 \mu \mathrm{g}$ versus $2 \mu \mathrm{g}$ of PTP construct). A so-called substrate-trapping mutant of 


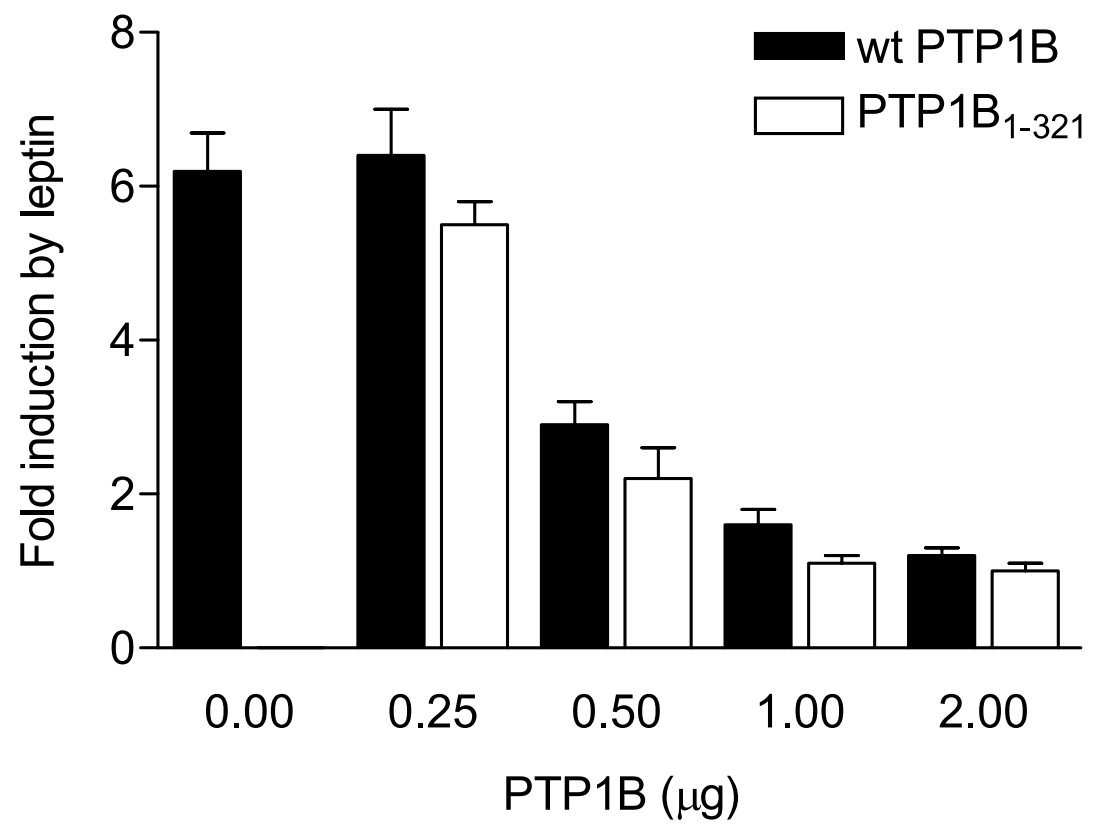

Figure 1 Dose-dependent inhibition of leptin-induced transcription by PTP1B. CHO cells $\left(4 \times 10^{5}\right)$ were transiently transfected with expression plasmids encoding the leptin receptor $(1.5 \mu \mathrm{g})$, a STAT3-responsive CAT reporter $(1.5 \mu \mathrm{g}), \beta$-galactosidase $(3 \mu \mathrm{g})$ and the indicated amount of wt PTP1B or the truncated form PTP1B 1-321 $_{1}$ as indicated on the graph. Cells were stimulated with $200 \mathrm{ng} / \mathrm{ml}$ leptin for $24 \mathrm{~h}$ and CAT and $\beta$-galactosidase activities were measured. The fold induction by leptin of CAT activity normalised to $\beta$-galactosidase activity is shown. The means with S.D. of three independent experiments are shown.

PTP1B, PTP1B ${ }_{\mathrm{D} 181 \mathrm{~A}}$ (Flint et al. 1997), which displays very weak catalytic activity, was not able to inhibit the leptin-induced CAT activity at any dose tested $(0 \cdot 25-2 \mu \mathrm{g}$ PTP construct) (Fig. 2), thus demonstrating that the PTP1B catalytic activity is required for inhibition. In addition to PTP1B, previous reports have provided evidence supporting a negativeregulatory role of both LAR (Ahmad et al. 1997, Zabolotny et al. 2004) and PTP $\alpha$ (Møller et al. 1995, Cong et al. 1999, Calera et al. 2000) in insulin signalling, though the exact level at which these phosphatases affect the signal transmission remains to be fully elucidated. As with PTP1B, the phosphatases SHP-2 (Li \& Friedman 1999, You et al. 1999, Yu et al. 2000) and CD45 (Irie-Sasaki et al. 2001, Yamada et al. 2002) seem to influence different signalling events by regulation of the JAK/STAT pathways. To evaluate whether the observed reduction in reporter activity was specific to PTP1B or a common feature shared by distantly related PTPs, we co-transfected the CHO cells with LAR, PTP $\alpha$, SHP-2 or CD45 at doses up to $2 \mu \mathrm{g}$ PTP construct and measured the STAT3-dependent reporter activity. With the exception of LAR, neither of the PTPs was able to inhibit leptin-induced CAT activity (Fig. 3). However, co-transfection with $2 \mu \mathrm{g}$ LAR construct resulted in an approximately $50 \%$ reduction of leptin-stimulated reporter activity.

\section{JAK2 and STAT3 are dephosphorylated by PTP1B in vitro}

To identify the mechanism by which PTP1B mediates its inhibitory effect on leptin signalling, we tested the ability of recombinant PTP1B and other PTPs to dephosphorylate JAK2 and STAT3 in vitro, i.e. in preparations of phosphorylated GST-JAK2 fusion proteins and in nuclear extract isolated from leptin-stimulated HEK293 cells respectively. A significant and time-dependent dephosphorylation of both JAK2 and STAT3 proteins was induced by PTP1B, resulting in an approximately $90 \%$ reduction in the phosphorylation level after $20 \mathrm{~min}$ (Fig. 4). In the presence of LAR, the STAT3 proteins but not the JAK2 proteins were slightly dephosphorylated (Fig. 4B). In contrast, CD45 and PTPa were inefficient in catalysing dephosphorylation of JAK2 and STAT3, although we have previously demonstrated that these recombinant PTP constructs have full activity against pTyr substrates under similar conditions (Iversen et al. 2000, Lund et al. 2004).

\section{Inhibition of PTP1B enhances STAT3 activity}

To further access the specific role of PTP1B, we decided to analyse leptin-induced STAT3 DNA binding in cells using a selective PTP1B inhibitor, compound 1 


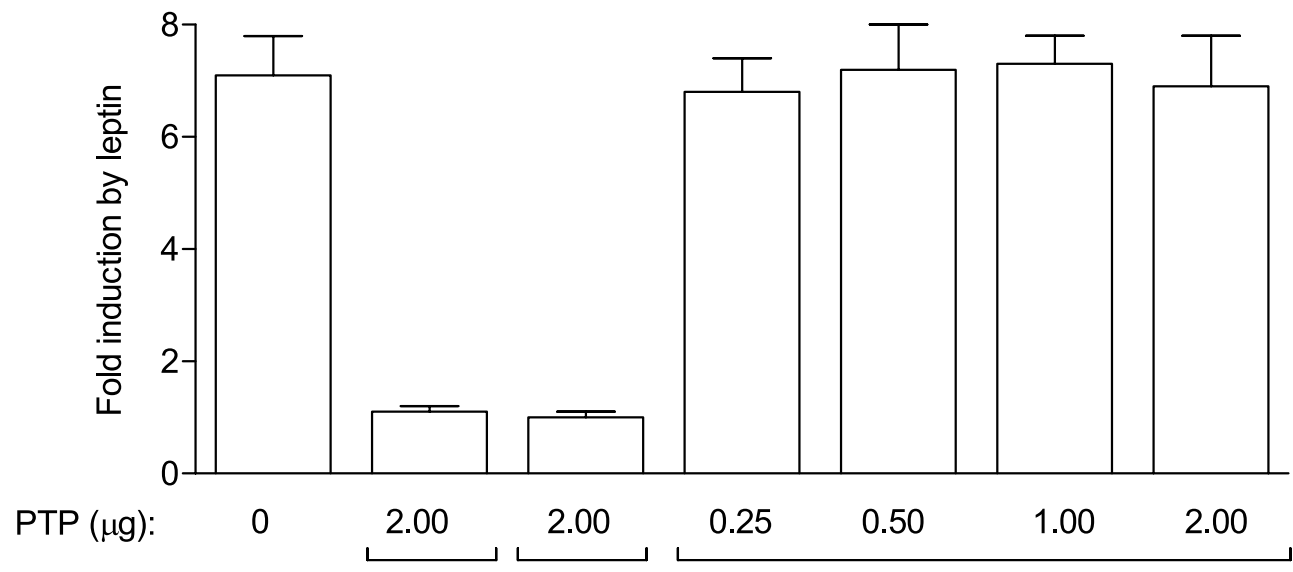

\section{wt PTP1B PTP1B 1-321}

PTP1B $18181 \mathrm{~A}$

Figure 2 The catalytic activity of PTP1B is required for inhibition of leptin signalling. $\mathrm{CHO}$ cells $\left(4 \times 10^{5}\right)$ were transiently transfected with expression plasmids encoding the leptin receptor $(1.5 \mu \mathrm{g})$, a STAT3-responsive CAT reporter $(1.5 \mu \mathrm{g}), \beta$-galactosidase $(3 \mu \mathrm{g})$ and the indicated amount of wt PTP1B, the truncated form PTP1B ${ }_{1-321}$ or the catalytically inactive mutant $\mathrm{PTP}_{1 \mathrm{~B}} \mathrm{D} 181 \mathrm{~A}_{\mathrm{A}}$ as indicated on the graph. Cells were stimulated with $200 \mathrm{ng} / \mathrm{ml}$ leptin for $24 \mathrm{~h}$ and CAT and $\beta$-galactosidase activities were measured. The fold induction by leptin of CAT activity normalised to $\beta$-galactosidase activity is shown. The means with S.D. of three independent experiments are shown.

(Fig. 5A) (Iversen et al. 2000). This compound inhibits PTP1B and its close homologue T-cell (TC)-PTP at pH $7 \cdot 0$ with inhibitor constant $\left(K_{\mathrm{i}}\right)$ values of $4 \cdot 7$ and $9 \cdot 4 \mu \mathrm{M}$ respectively (Andersen et al. 2002). As compound 1 was previously shown to display limited cell permeability, we decided to used a prodrug of compound 1, i.e. compound 2 (Fig. 5A), for which we have demonstrated an efficient uptake by Madin-Darby canine kidney cell monolayers - a standard cell line used to measure passive uptake in cells (Andersen et al. 2002). However, we also demonstrated a rapid hydrolysis of compound 2 upon exposure to serum. To test if compound 2 was sufficiently stable to allow uptake in our target cells as a prodrug, we investigated the kinetic properties of this inhibitor under conditions similar to those present in cellular systems. While compound 1 inhibited PTP1B

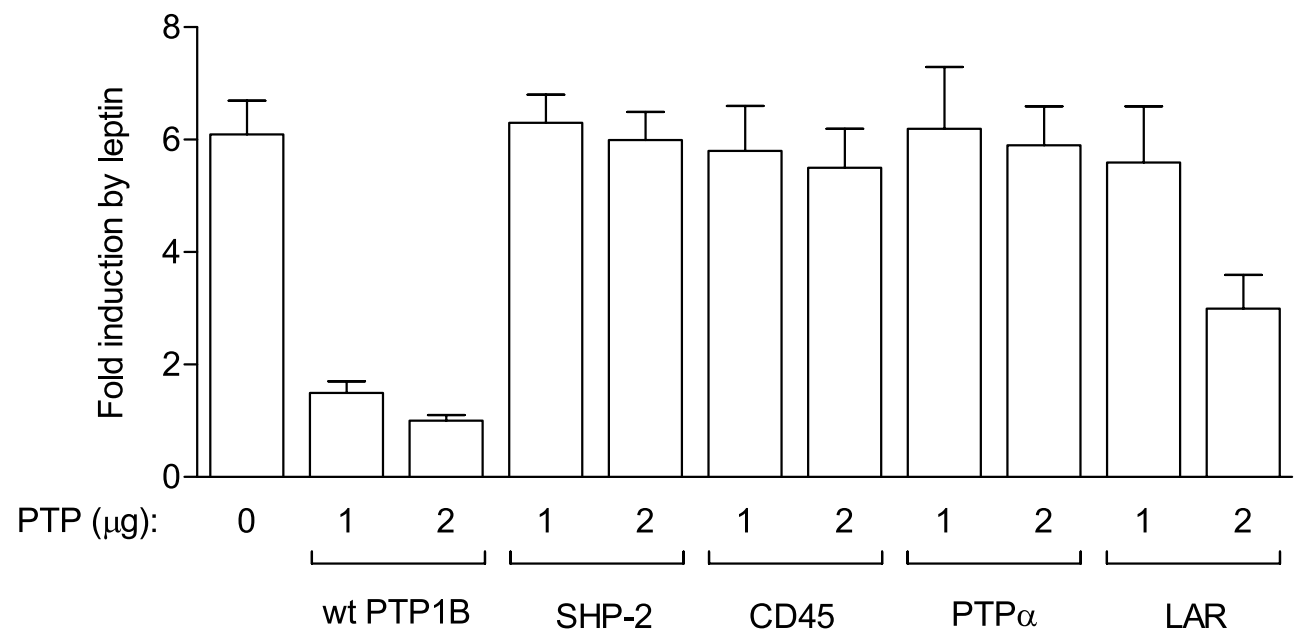

Figure 3 Selective PTP1B inhibition of leptin-induced transcription. $\mathrm{CHO}$ cells $\left(4 \times 10^{5}\right)$ were transiently transfected with expression plasmids encoding the leptin receptor $(1.5 \mu \mathrm{g})$, a STAT3-responsive CAT reporter $(1.5 \mu \mathrm{g}), \beta$-galactosidase $(3 \mu \mathrm{g})$ and PTP (i.e. PTP1B, SHP-2, CD45, PTP $\alpha$ or LAR as indicated on the graph). Cells were stimulated with $200 \mathrm{ng} / \mathrm{ml}$ leptin for $24 \mathrm{~h}$ and CAT and $\beta$-galactosidase activities were measured. The fold induction by leptin of CAT activity normalized to $\beta$-galactosidase activity is shown. The means with S.D. of three independent experiments are shown. 
(A)

PTP1B

CD45

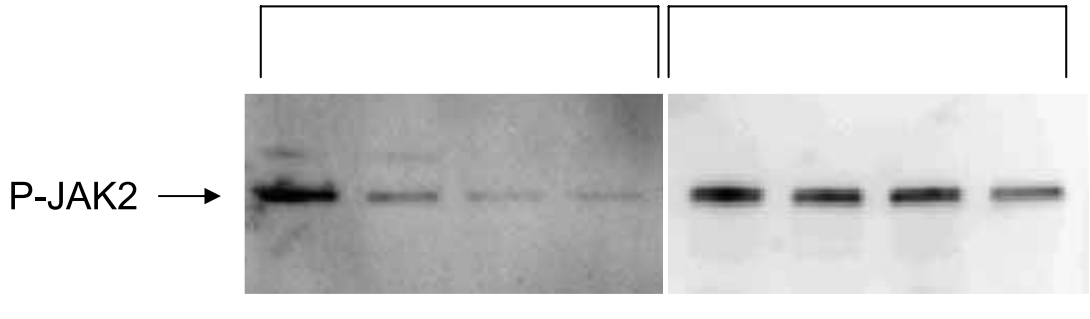

$\begin{array}{lllllllll}\text { Time (min.) } & 0 & 5 & 10 & 20 & 0 & 5 & 10 & 20\end{array}$

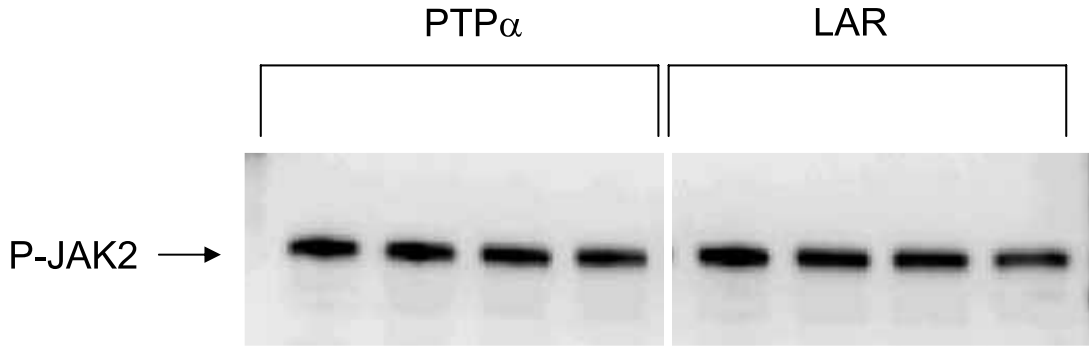

$\begin{array}{lllllllll}\text { Time (min.) } & 0 & 5 & 10 & 20 & 0 & 5 & 10 & 20\end{array}$

(B)

CD45

PTP1B

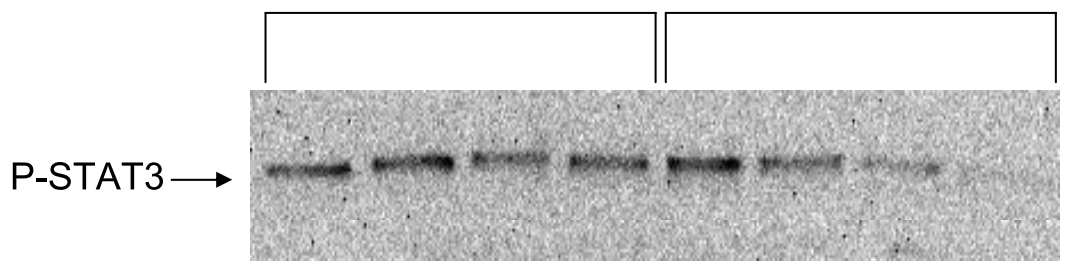

$\begin{array}{lllllllll}\text { Time (min.) } & 0 & 5 & 10 & 20 & 0 & 5 & 10 & 20\end{array}$

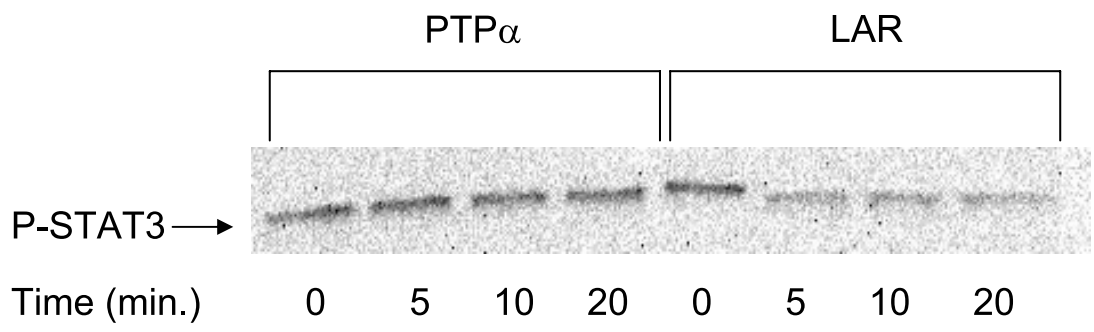

Figure 4 STAT3 and JAK2 are dephosphorylated by PTP1B in vitro. (A) Preparations of pTyr-JAK2-GST fusion proteins (400 ng) were incubated with recombinant PTPs for the indicated time-intervals. The JAK2 tyrosine phosphorylation status was determined by Western blotting using anti-pTyr antibody. The figure shows the time-dependent dephosphorylation of JAK2 following incubation with the indicated phosphatase. (B) Nuclear extracts $(5 \mu \mathrm{g})$ from leptin-stimulated HEK293 cells were incubated with recombinant PTPs for the indicated time-intervals. The STAT3 tyrosine phosphorylation status was determined by Western blotting using anti-pTyr 703 STAT3 antibodies. The figure shows the time-dependent dephosphorylation of STAT3 following incubation with the indicated phosphatase. Equal amounts of phosphatase activity based on pNPP hydrolysis were used in both assays. Representative blots are shown. 


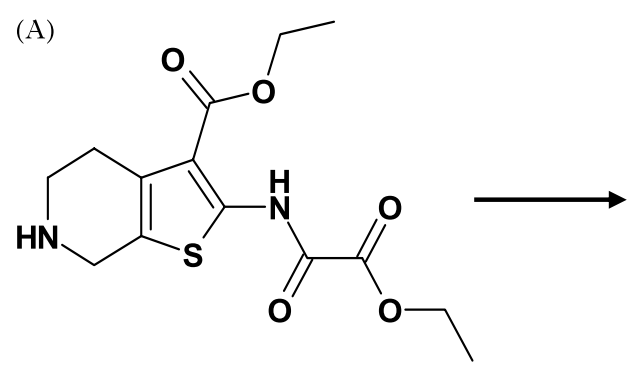

compound 2<smiles>O=C(O)C(=O)Nc1sc2c(c1C(=O)O)CCNC2</smiles>

compound 1

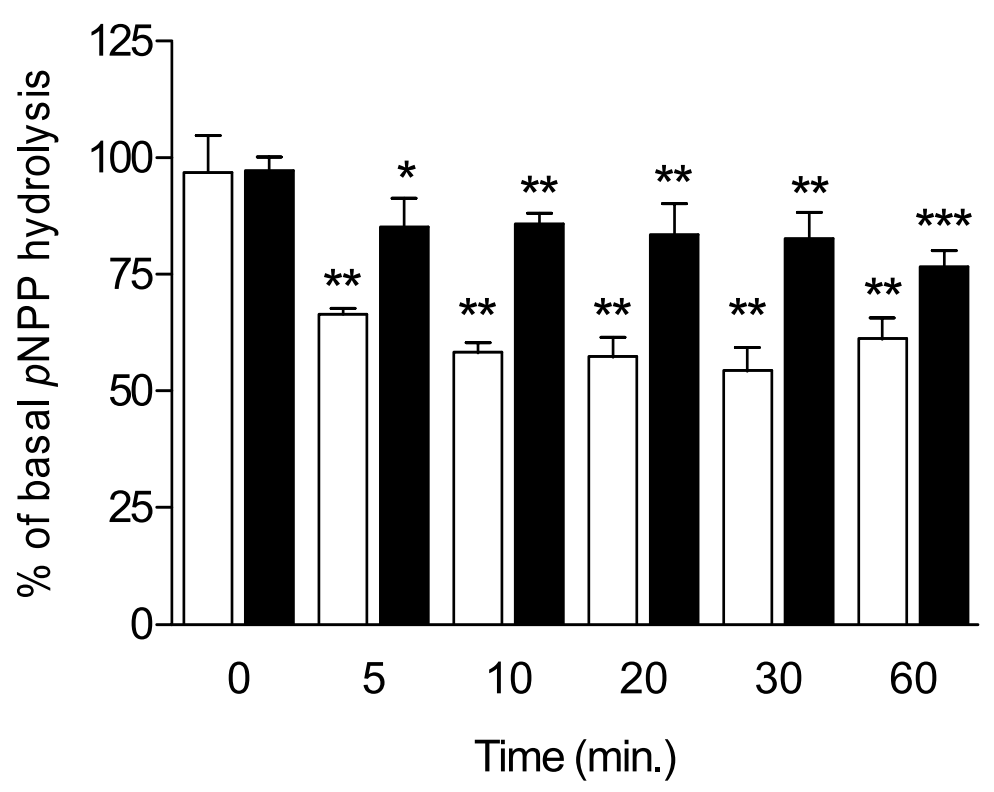

Figure $5(A)$.

throughout the incubation time, the inhibition by compound 2 was markedly time-dependent, with increased inhibition of the PTP1B-catalysed hydrolysis of $p$ NPP as a function of time (Fig. 5A). This result demonstrated the presence of a slow hydrolysis of compound 2, affording the active di-acid inhibitor (compound 1, schematic illustration in Fig. 5A). In conclusion, these studies demonstrated that the prodrug compound 2 is sufficiently stable for passage of the cell membrane under the given assay conditions, as well as being sufficiently labile for intracellular release of the active PTP1B inhibitor, compound 1, and thus appropriate for application to our target cells.

HEK293 cells stably transfected with the leptin receptor constitute a suitable cellular model system, in which STAT3-dependent DNA binding activity was induced by leptin after 10 and $30 \mathrm{~min}$ of stimulation, as measured by EMSA of nuclear extracts (Fig. 5B). Incubation of the cells in the presence of compound 2 clearly enhanced the response to leptin, by approximately 2.5-fold (Fig. 5C), indicating an inhibition of PTP1B and thus a role of this endogenous phosphatase in the suppression of leptin-induced STAT3 activity. It should, however, be noted that the enhanced leptin-induced STAT3 activity observed in the presence of compound 2 cannot be differentiated to an effect on either PTP1B or TC-PTP, as the parent compound displays similar affinity towards the two PTPs. Collectively, these results provide evidence for the negative regulatory role of $\mathrm{PTP} 1 \mathrm{~B}$ on leptin signalling to be mediated by dephosphorylation of JAK2 and STAT3, subsequently leading to inactivation at the level of both these important proteins.

\section{Discussion}

Genetic and biochemical evidence for the important role of PTP1B as a negative regulator of insulin- and 


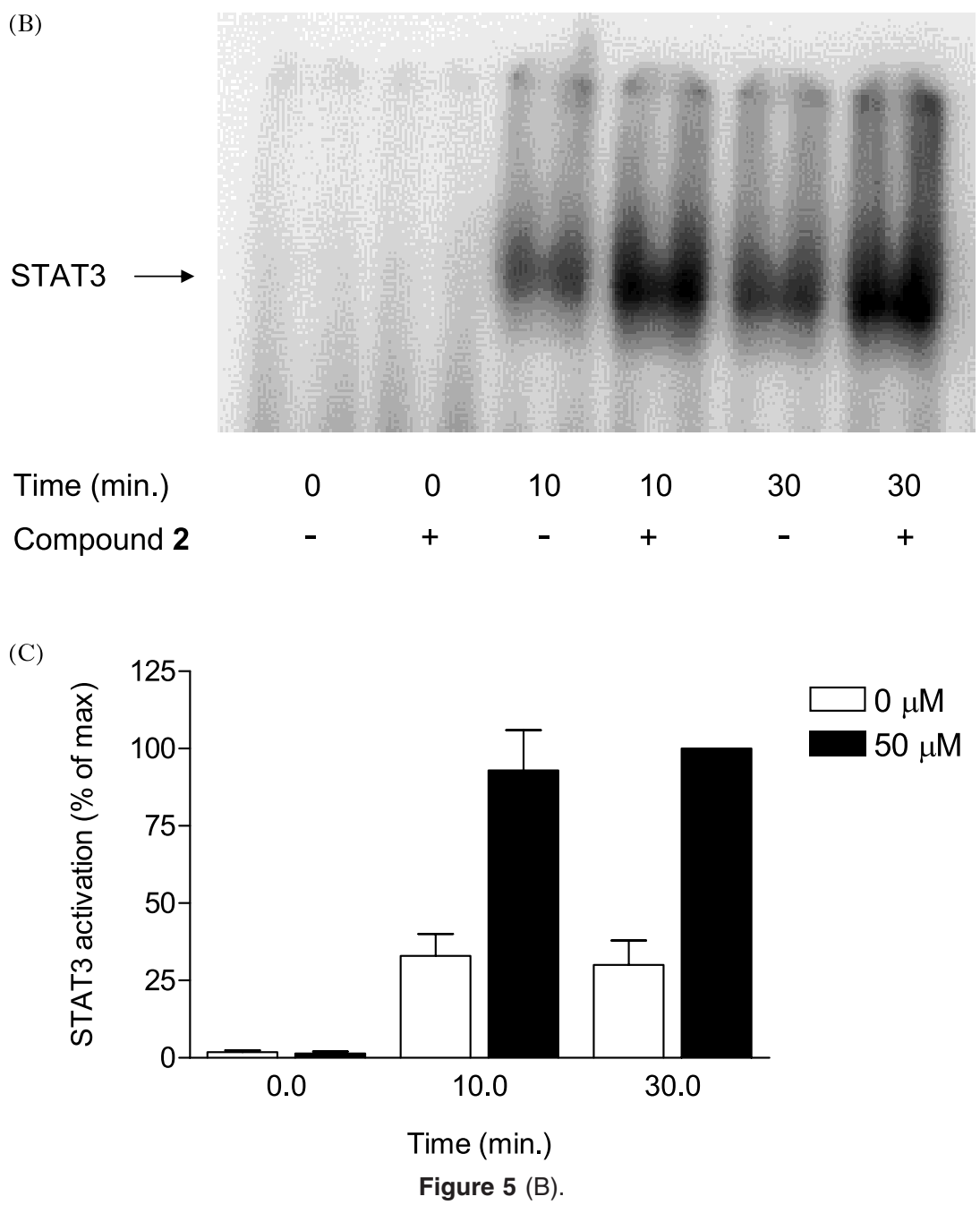

Figure 5 Selective inhibition of PTP1B enhances leptin-induced STAT3 DNA binding in cells. (A) The upper panel is a schematic illustration of the conversion of compound 2 to compound 1 upon cleavage by esterases. Lower panel: PTP1B-catalysed $p$ NPP hydrolysis in the presence of $50 \mu \mathrm{M}$ compound 1 (open bars) or 2 (solid bars). Results are presented as percentage of basal pNPP hydrolysis in the absence of inhibitor (i.e. $100 \%)$. The means with S.D. of four independent experiments are shown. Significance between mean at 0 min versus mean at time $t$ is accepted at $P<0.05\left(^{*}\right), P<0.01\left(^{(*}\right)$ and $P<0.001\left(^{* * *}\right)$. (B) HEK293 cells expressing the human leptin receptor were stimulated with $200 \mathrm{ng} / \mathrm{ml}$ leptin for the indicated time in the absence or presence of $50 \mu \mathrm{M}$ compound 2. Nuclear extracts were prepared and STAT3 DNA binding activity was measured by EMSA using the m67SIE probe. A representative EMSA is shown. (C) Quantitation by ImageQuant analysis of the EMSA experiments described in (B). Results are presented as percent of maximal STAT3 binding activity in the absence (open bars) or presence of $50 \mu \mathrm{M}$ of compound 2 (solid bars). The means with S.D. of three independent experiments are shown.

leptin-induced metabolic actions have emerged in recent years. In particular, the increased insulin sensitivity, resistance to diet-induced obesity and augmented energy expenditure observed in PTP1B-deficient mice (Elchebly et al. 1999, Klaman et al. 2000), together with the enhanced phosphorylation levels of insulin and/or leptin signalling molecules in vivo and in several cell lines (Elchebly et al. 1999, Klaman et al. 2000, Cheng et al. 2002, Zabolotny et al. 2002) have established an important link between the two signalling pathways and suggest PTP1B as a key therapeutic target in obesity and type 2 diabetes. In this study, we have provided evidence 
for a negative regulatory role of PTP1B on leptin signalling, mediated through a direct and timedependent dephosphorylation of both JAK2 and STAT3.

First, we identified PTP1B as a negative regulator of leptin signalling in $\mathrm{CHO}$ cells by demonstrating a significant and dose-dependent inhibition of leptininduced transcription by wt PTP1B (Fig. 1). For these experiments, a leptin-responsive part of the insulin promoter was used and it should be noted that this promoter region is responsive to transcription factors other than STAT3, and thus that the observed effect of PTP1B might not be exclusively mediated through inhibition of the JAK/STAT pathway. Importantly, the inhibition required the catalytic activity but was independent of the presence of the C-terminal end of the enzyme, i.e. wt PTP1B and PTP1B ${ }_{1-321}$ but not $\mathrm{PTP} \mathrm{B}_{\mathrm{D} 181 \mathrm{~A}}$ inhibited leptin-induced reporter activity (Fig. 2). A number of recent publications have illustrated reduced leptin signalling and decreased amounts of pTyr-STAT3 in the presence of PTP1B in various cellular systems, such as fibroblast and Cos-7 cells (Zabolotny et al. 2002) as well as the murine hypothalamic cell line, GT1-7 (Kaszubska et al. 2002), while increased pTyr-STAT3 levels were observed in hypothalamic tissue from PTP1B-deficient mice (Cheng et al. 2002, Zabolotny et al. 2002). In the present study, the incubation of nuclear extract containing pTyrSTAT3 proteins with recombinant PTP1B was demonstrated to result in a time-dependent dephosphorylation of STAT3 (Fig. 4C).

The PTP1B-mediated dephosphorylation of JAK2 is believed to occur at or near the endoplasmic reticulum, as Tremblay, Boisclair and colleagues have recently provided evidence for a direct interaction between the endoplasmic reticulum-bound form of PTP1B (Frangioni et al. 1992) and JAK2 proteins to be feasible (Gu et al. 2003). The sequence [D/E]-Y-Y-[R/K], demonstrated to constitute a consensus substrate recognition motif for $\mathrm{PTP} 1 \mathrm{~B}$, is present in several proteins including JAK2, TYK2 (Myers et al. 2001) and the insulin receptor (Salmeen et al. 2000). Interestingly, a similar motif with either mono or tandem tyrosine residues preceded by acidic residues, indicative of a potential genuine substrate for PTP1B action, is absent in STAT3 proteins. However, other proteins have been demonstrated to serve as substrate for PTP1B using a different motif, such as the $\mathrm{SH} 3$ domain in p130cas protein, assumed to interact with proline-rich stretches of PTP1B (Yu et al. 1994, Liu et al. 1996). While the cellular compartment within which PTP1B induces dephosphorylation of STAT3 remains to be determined, a recent study has indicated that prolactin-induced STAT5 phosphorylation and nuclear translocation is reduced upon over-expression of PTP1B in COS7 cells (Aoki \& Matsuda 2000), suggesting that the PTP1B- induced dephosphorylation of STAT3 observed in the present study occurs in the cytosol.

Valuable information on the function of specific genes at the molecular level can be obtained from cell lines, such as (i) cancer cell lines with specific chromosomal deletions and (ii) cell lines derived from knockout animals. Similarly, gene silencing with RNA interference and oligonucleotide antisense techniques have provided important information (Blaskovich \& Kim 2002, Andersen et al. 2004, Dubé \& Tremblay 2004). However, these approaches have certain limitations as counter-regulatory mechanisms such as up- or downregulation of other genes may mask the functionality of the gene in question and thus prevent a correct interpretation of the situation. Similar compensatory mechanisms may be at play in antisense studies, which in addition depend on the turnover of the gene product, i.e. a long half-life of a specific protein may prevent the use of this technique in primary cells. To analyse in more detail the effect of PTP1B as a negative regulator of leptin signalling, we have used a highly selective inhibitor of PTP1B. In contrast to the above approaches, such inhibitors allow direct assessment of the function of PTP1B - provided that sufficient specificity for the particular enzyme can be obtained.

We have previously demonstrated that compound 1 is highly selective for PTP1B and the homologous TG-PTP (Iversen et al. 2002). Using a prodrug of compound 1 , we have here demonstrated a significant increase in leptin-induced STAT3 DNA binding activity, most likely produced by specific inhibition of endogenously expressed PTP1B and/or TG-PTP.

While recent studies have identified TC-PTP as a phosphatase responsible for dephosphorylation of STAT1 in the nucleus (ten Hoeve et al. 2002), it was found that PTP1B, but not TC-PTP, could attenuate growth hormone-mediated JAK2 dephosphorylation (Gu et al. 2003). Thus, despite the fact that PTP1B and TC-PTP have a sequence identity of $74 \%$ in the catalytic domains (Iversen et al. 2002), it seems that subtle structural differences and/or distinct subcellular localisation are responsible for the reported different substrate specificities and dissimilar biological functions of these highly homologues PTPs (Tiganis et al. 1998, Simoncic et al. 2002, Gu et al. 2003, Pasquali et al. 2003, Persson et al. 2004). This difference is also evident from the strikingly different phenotypes of PTP1B- versus TC-PTP-deficient mice (You-Ten et al. 1997, Elchebly et al. 1999, Klaman et al. 2000, Heinonen et al. 2004).

Several lines of evidence have pointed towards negative regulatory roles of LAR (Ahmad et al. 1997, Zabolotny et al. 2004) and PTPa (Cong et al. 1999, Møller et al. 1995, Calera et al. 2000) in the insulin signalling pathway, whereas SHP-2 (Li \& Friedman 1999, You et al. 1999, Yu et al. 2000) and CD45 (Irie-Sasaki et al. 2001, Yamada et al. 2002) seem to 
operate on distinct cytokine-induced signal transduction cascades. In the present study, PTP $\alpha$, SHP-2 and CD45 did not influence leptin-stimulated transcription or the phosphorylation level of JAK2 and STAT3, indicating a selective action of PTP1B on leptin signalling. The lack of activity of GD45 on JAK2 and STAT3 is in contrast to a previous study, in which CD45 was shown to be a potential negative regulator of JAK proteins in haematopoietic cell types (Irie-Sasaki et al. 2001). This discrepancy may be attributable to the fact that different cellular systems and stimulatory factors were used, as compared with the current conditions.

The present study has demonstrated a reduced leptin-induced transcription and a time-dependent dephosphorylation of STAT3 in the presence of LAR, suggesting a potential role of this PTP in the regulation of leptin signalling. An inhibitory effect of LAR on pTyr-STAT3 or any other members of the JAK/STAT pathway has not been previously illustrated, although prior reports describing potential cross-talk between leptin and insulin signalling and JAK/STAT proteins may support such an effect of LAR on STAT3 (Ahmad \& Goldstein 1995, Ahmad et al. 1997, Cheng et al. 2002, Zabolotny et al. 2002, 2004).

In summary, we have identified PTP1B as a negative regulator of the leptin signalling, most likely mediated by direct interaction with both JAK2 and STAT3. Importantly, these findings were supported by experiments with a selective PTP1B inhibitor prodrug, which significantly enhanced leptin-induced STAT3 activation presumably by direct inhibition of endogenous PTP1B and/or its close homologue TC-PTP.

\section{Acknowledgement}

The authors declare that there is no conflict of interest that would prejudice the impartiality of this scientific work.

\section{References}

Ahima RS \& Flier JS 2000 Leptin. Annual Review of Physiology 62 413-437.

Ahmad F \& Goldstein BJ 1995 Purification, identification and subcellular distribution of three predominant protein-tyrosine phosphatase enzymes in skeletal muscle tissue. Biochimica et Biophysica Acta - Protein Structure and Molecular Enzymology 1248 57-69.

Ahmad F, Azevedo. JL, Cortright R, Dohm GL \& Goldstein BJ 1997 Alterations in skeletal muscle protein-tyrosine phosphatase activity and expression in insulin-resistant human obesity and diabetes. Fournal of Clinical Investigation 100 449-458.

Andersen HS, Iversen LF, Jeppesen CB, Branner S, Norris K, Rasmussen HB, Møller KB \& Møller NPH 2000

2-(Oxalylamino)-benzoic acid is a general, competitive inhibitor of protein-tyrosine phosphatases. Fournal of Biological Chemistry $\mathbf{2 7 5}$ 7101-7108.
Andersen HS, Olsen OH, Iversen LF, Sorensen ALP, Mortensen SB, Christensen MS, Branner S, Hansen TK, Lau JF, Jeppesen L, Moran EJ, Su J, Bakir F, Judge L, Shahbaz M, Collins T, Vo T, Newman MJ, Ripka WC \& Møller NPH 2002 Discovery and SAR of a novel selective and orally bioavailable nonpeptide classical competitive inhibitor class of protein-tyrosine phosphatase 1B. Journal of Medicinal Chemistry 45 4443-4459.

Andersen JN, Jansen PG, Echwald SM, Mortensen OH, Fukada T, Del Vecchio RL, Tonks NK \& Møller NPH 2004 A genomic perspective on protein tyrosine phosphatases: gene structure, pseudogenes, and genetic disease linkage. FASEB fournal 18 8-30.

Aoki N \& Matsuda T 2000 A cytosolic protein-tyrosine phosphatase PTP1B specifically dephosphorylates and deactivates prolactin-activated STAT5a and STAT5b. Fournal of Biological Chemistry 275 39718-39726.

Banks WA 2003 Is obesity a disease of the blood-brain barrier? Physiological, pathological, and evolutionary considerations. Current Pharmaceutical Design 9 801-809.

Bjørbæk C, El Haschimi K, Frantz JD \& Flier JS 1999 The role of SOCS-3 in leptin signaling and leptin resistance. Fournal of Biological Chemistry 274 30059-30065.

Blaskovich MA \& Kim HO 2002 Recent discovery and development of protein tyrosine phosphatase inhibitors. Expert Opinion on Therapeutic Patents 12 871-905.

Calera MR, Vallega G \& Pilch PF 2000 Dynamics of protein-tyrosine phosphatases in rat adipocytes. Fournal of Biological Chemistry 275 6308-6312.

Chen C \& Okayama H 1987 High-efficiency transformation of mammalian cells by plasmid DNA. Molecular and Cellular Biology 7 2745-2752.

Cheng A, Uetani N, Simoncic PD, Chaubey VP, Lee-Loy A, McGlade CJ, Kennedy BP \& Tremblay ML 2002 Attenuation of leptin action and regulation of obesity by protein tyrosine phosphatase 1B. Developmental Cell 2 497-503.

Clement K, Vaisse C, Lahlou N, Cabrol S, Pelloux V, Cassuto D, Gourmelen M, Dina C, Chambaz J, Lacorte JM, Basdevant A, Bougnè res P, Lebouc Y, Froguel P \& Guy-Grand B 1998 A mutation in the human leptin receptor gene causes obesity and pituitary dysfunction. Nature 392 398-401.

Cong LN, Chen H, Li Y, Lin CH, Sap J \& Quon MJ 1999 Overexpression of protein tyrosine phosphatase $\alpha$; (PTP- $\alpha$ ) but not PTP- $\kappa$ inhibits translocation of GLUT4 in rat adipose cells. Biochemical and Biophysical Research Communications $\mathbf{2 5 5}$ 200-207.

Cui YX, Huang L, Elefteriou F, Yang GQ, Shelton JM, Giles JE, Oz OK, Pourbahrami T, Lu CYH, Richardson JA, Karsenty G \& Li C 2004 Essential role of STAT3 in body weight and glucose homeostasis. Molecular and Cellular Biology 24 258-269.

Dubé N \& Tremblay ML 2004 Beyond the metabolic function of PTP1B. Cell Cycle 3 550-553.

Elchebly M, Payette P, Michaliszyn E, Cromlish W, Collins S, Lee-Loy A, Normandin D, Cheng A, Himms-Hagen J, Chan C, Ramachandran C, Gresser MJ, Tremblay ML \& Kennedy BP 1999 Increased insulin sensitivity and obesity resistance in mice lacking the protein tyrosine phosphatase-1B gene. Science $\mathbf{2 8 3}$ $1544-1548$.

El Haschimi K, Pierroz DD, Hileman SM, Bjørbæk C \& Flier JS 2000 Two defects contribute to hypothalamic leptin resistance in mice with diet-induced obesity. Fournal of Clinical Investigation 105 1827-1832.

Flint AJ, Tiganis T, Barford D \& Tonks NK 1997 Development of 'substrate-trapping' mutants to identify physiological substrates of protein tyrosine phosphatases. PNAS 94 1680-1685.

Frangioni JV, Beahm PH, Shifrin V, Jost CA \& Neel BG 1992 The nontransmembrane tyrosine phosphatase PTP-1B localizes to the endoplasmic reticulum via its 35 amino acid $\mathrm{C}$-terminal sequence. Cell 68 545-560. 
Gadina M, Hilton D, Johnston JA, Morinobu A, Lighvani A, Zhou YJ, Visconti R \& O'Shea JJ 2001 Signaling by type I and II cytokine receptors: ten years after. Current Opinion in Immunology 13 363-373.

Galsgaard ED, Gouilleux F, Groner B, Serupt P, Nielsen JH \& Billestrup N 1996 Identification of a growth hormone-responsive STAT5-binding element in the rat insulin 1 gene. Molecular Endocrinology $10652-660$.

Gu F, Dubé N, Kim JW, Cheng A, De Jesus IS, Tremblay ML \& Boisclair YR 2003 Protein tyrosine phosphatase 1B attenuates growth hormone-mediated JAK2-STAT signaling. Molecular and Cellular Biology 23 3753-3762.

Gum RJ, Gaede LL, Koterski SL, Heindel M, Clampit JE, Zinker BA, Trevillyan JM, Ulrich RG, Jirousek MR \& Rondinone CM 2003 Reduction of protein tyrosine phosphatase 1B increases insulin-dependent signaling in ob/ob mice. Diabetes 52 21-28.

Haspel RL, Salditt-Georgieff M \& Darnell JE 1996 The rapid inactivation of nuclear tyrosine phosphorylated Statl depends upon a protein tyrosine phosphatase. EMBO Fournal 15 $6262-6268$.

Heinonen KM, Nestel FP, Newell EW, Charette G, Seemayer TA, Tremblay ML \& Lapp WS 2004 T-cell protein tyrosine phosphatase deletion results in progressive systemic inflammatory disease. Blood 103 3457-3464.

ten Hoeve J, de Jesus Ibarra-Sanchez M, Fu Y, Zhu W, Tremblay ML, David M \& Shuai K 2002 Identification of a nuclear Statl protein tyrosine phosphatase. Molecular and Cellular Biology 22 $5662-5668$.

Ihle JN \& Kerr IM 1995 Jaks and Stats in signaling by the cytokine receptor superfamily. Trends in Genetics 11 69-74.

Irie-Sasaki J, Sasaki T, Matsumoto W, Opavsky A, Cheng M, Welstead G, Griffiths E, Krawczyk C, Richardson CD, Aitken K, Iscove N, Koretzky G, Johnson P, Liu P, Rothstein DM \& Penninger JM 2001 CD45 is a JAK phosphatase and negatively regulates cytokine receptor signalling. Nature $\mathbf{4 0 9}$ 349-354.

Iversen LF, Andersen HS, Branner S, Mortensen SB, Peters GH, Norris K, Olsen OH, Jeppesen CB, Lundt BF, Ripka W, Møller KB \& Møller NPH 2000 Structure-based design of a low molecular weight, nonphosphorus, nonpeptide, and highly selective inhibitor of protein-tyrosine phosphatase 1B. Fournal of Biological Chemistry 275 10300-10307.

Iversen LF, Andersen HS, Møller KB, Olsen OH, Peters GH, Branner S, Mortensen SB, Hansen TK, Lau J, Ge Y, Holsworth DD, Newman MJ \& Møller NPH 2001 Steric hindrance as a basis for structure-based design of selective inhibitors of protein-tyrosine phosphatases. Biochemistry 40 14812-14820.

Iversen LF, Møller KB, Pedersen AK, Peters GH, Petersen AS, Andersen HS, Branner S, Mortensen SB \& Møller NPH 2002 Structure determination of $\mathrm{T}$ cell protein-tyrosine phosphatase. Fournal of Biological Chemistry 277 19982-19990.

Kaszubska W, Falls HD, Schaefer VG, Haasch D, Frost L, Hessler P, Kroeger PE, White DW, Jirousek MR \& Trevillyan JM 2002 Protein tyrosine phosphatase $1 \mathrm{~B}$ negatively regulates leptin signaling in a hypothalamic cell line. Molecular and Cellular Endocrinology 195 109-118.

Klaman LD, Boss O, Peroni OD, Kim JK, Martino JL, Zabolotny JM, Moghal N, Lubkin M, Kim YB, Sharpe AH,

Stricker-Krongrad A, Shulman GI, Neel BG \& Kahn BB 2000 Increased energy expenditure, decreased adiposity, and tissue-specific insulin sensitivity in protein-tyrosine phosphatase 1B-deficient mice. Molecular and Cellular Biology 20 5479-5489.

Kloek C, Haq AK, Dunn SL, Lavery HJ, Banks AS \& Myers MG 2002 Regulation of Jak kinases by intracellular leptin receptor sequences. Fournal of Biological Chemistry 277 41547-41555.

Korner J \& Aronne LJ 2003 The emerging science of body weight regulation and its impact on obesity treatment. Fournal of Clinical Investigation $111565-570$.
Kushner JA, Haj FG, Klaman LD, Dow MA, Kahn BB, Neel BG \& White MF 2004 Islet-sparing effects of protein tyrosine phosphatase-1b deficiency delays onset of diabetes in IRS2 knockout mice. Diabetes 53 61-66.

Levy DE \& Darnell JE 2002 STATs: transcriptional control and biological impact. Nature Reviewes Molecular Cell Biology 3 651-662.

Li C \& Friedman JM 1999 Leptin receptor activation of SH2 domain containing protein tyrosine phosphatase 2 modulates $\mathrm{Ob}$ receptor signal transduction. PNAS 96 9677-9682.

Liu F, Hill DE \& Chernoff J 1996 Direct binding of the proline-rich region of protein tyrosine phosphatase $1 \mathrm{~B}$ to the Src homology 3 domain of p130-Cas. Fournal of Biological Chemistry 271 31290-31295.

Lund IK, Andersen HS, Iversen LF, Olsen OH, Møller KB, Pedersen AK, Ge Y, Holsworth DD, Newman MJ, Axe FU \& Møller NPH 2004 Structure-based design of selective and potent inhibitors of protein-tyrosine phosphatase $\beta$. Fournal of Biological Chemistry 279 24226-24235.

Myers MP, Andersen JN, Cheng A, Tremblay ML, Horvath CM, Parisien JP, Salmeen A, Barford D \& Tonks NK 2001 TYK2 and JAK2 are substrates of protein-tyrosine phosphatase 1B. Fournal of Biological Chemistry 276 47771-47774.

Møller NPH, Møller KB, Lammers R, Kharitonenkov A, Hoppe E, Wiberg FC, Sures I \& Ullrich A 1995 Selective down-regulation of the insulin receptor signal by protein-tyrosine phosphatases $\alpha$ and $\varepsilon$. Fournal of Biological Chemistry 270 23126-23131.

Pasquali C, Curchod ML, Wä lchli S, Espanel X, Guerrier M, Arigoni F, Strous G \& van Huijsduijnen RH 2003 Identification of protein tyrosine phosphatases with specificity for the ligand-activated growth hormone receptor. Molecular Endocrinology 17 2228-2239.

Persson C, Sä venhed C, Bourdeau A, Tremblay ML, Markova B, Böhmer FD, Haj FG, Neel BG, Elson A, Heldin CH, Rönnstrand L, Östman A \& Hellberg C 2004 Site-selective regulation of platelet-derived growth factor $\beta$ receptor tyrosine phosphorylation by T-cell protein tyrosine phosphatase. Molecular and Cellular Biology 24 2190-2201.

Richter HE, Albrektsen T \& Billestrup N 2003 The role of signal transducer and activator of transcription 5 in the inhibitory effects of GH on adipocyte differentiation. Fournal of Molecular Endocrinology 30 139-150.

Rondinone CM, Trevillyan JM, Clampit J, Gum RJ, Berg C, Kroeger P, Frost L, Zinker BA, Reilly R, Ulrich R, Butler M, Monia BP, Jirousek MR \& Waring JF 2002 Protein tyrosine phosphatase $1 \mathrm{~B}$ reduction regulates adiposity and expression of genes involved in lipogenesis. Diabetes 51 2405-2411.

Salmeen A, Andersen JN, Myers MP, Tonks NK \& Barford D 2000 Molecular basis for the dephosphorylation of the activation segment of the insulin receptor by protein tyrosine phosphatase 1B. Molecular Cell 6 1401-1412.

Simoncic PD, Lee-Loy A, Barber DL, Tremblay ML \& McGlade CJ 2002 The $\mathrm{T}$ cell protein tyrosine phosphatase is a negative regulator of janus family kinases 1 and 3. Current Biology 12 446-453.

Stofega MR, Herrington J, Billestrup N \& Carter-Su C 2000 Mutation of the SHP-2 binding site in growth hormone $(\mathrm{GH})$ receptor prolongs GH-promoted tyrosyl phosphorylation of GH receptor, JAK2, and STAT5B. Molecular Endocrinology 14 $1338-1350$

Sweeney G 2002 Leptin signalling. Cellular Signalling 14 655-663.

Tartaglia LA 1997 The leptin receptor. Fournal of Biological Chemistry 272 6093-6096.

Tartaglia LA, Dembski M, Weng X, Deng N, Culpepper J, Devos R, Richards GJ, Campfield LA, Clark FT, Deeds J, Muir C, Sanker S, Moriarty A, Moore KJ, Smutko JS, Mays GG, Woolf EA, Monroe CA \& Tepper RI 1995 Identification and expression cloning of a leptin receptor, OB-R. Cell $\mathbf{8 3}$ $1263-1271$ 
Tiganis T, Bennett AM, Ravichandran KS \& Tonks NK 1998 Epidermal growth factor receptor and the adaptor protein p52 Shc are specific substrates of T-cell protein tyrosine phosphatase. Molecular and Cellular Biology 18 1622-1634.

Tonks NK, Diltz CD \& Fischer EH 1988 Characterization of the major protein-tyrosine-phosphatases of human placenta. Fournal of Biological Chemistry 263 6731-6737.

Yamada T, Zhu D, Saxon A \& Zhang K 2002 CD45 controls interleukin-4-mediated IgE class switch recombination in human B cells through its function as a Janus kinase phosphatase. Fournal of Biological Chemistry 277 28830-28835.

You M, Yu DH \& Feng GS 1999 Shp-2 tyrosine phosphatase functions as a negative regulator of the interferon-stimulated Jak/STAT pathway. Molecular and Cellular Biology 19 2416-2424.

You-Ten KE, Muise ES, Itié A, Michaliszyn E, Wagner J, Jothy S, Lapp WS \& Tremblay ML 1997 Impaired bone marrow microenvironment and immune function in $\mathrm{T}$ cell protein tyrosine phosphatase-deficient mice. Fournal of Experimental Medicine 186 683-693.

Yu H, Chen JK, Feng S, Dalgarno DC, Brauer AW \& Schreiber SL 1994 Structural basis for the binding of proline-rich peptides to SH3 domains. Cell 76 933-945.

Yu C, Jin Y \& Burakoff SJ 2000 Cytosolic tyrosine dephosphorylation of STAT5: potential role of SHP-2 in STAT5 regulation. Fournal of Biological Chemistry 275 599-604.
Zabolotny JM, Bence-Hanulec KK, Stricker-Krongrad A, Haj F, Wang YP, Minokoshi Y, Kim YB, Elmquist JK, Tartaglia LA, Kahn BB \& Neel BG 2002 PTP1B regulates leptin signal transduction in vivo. Developmental Cell $\mathbf{2}$ 489-495.

Zabolotny JM, Haj FG, Kim YB, Kim HJ, Shulman GI, Kim JK, Neel BG \& Kahn BB 2004 Transgenic overexpression of PTP1B in muscle causes insulin resistance but overexpression with LAR does not additively impair insulin action. Fournal of Biological Chemistry $27924844-24851$.

Zhang Y, Proenca R, Maffei M, Barone M, Leopold L \& Friedman JM 1994 Positional cloning of the mouse obese gene and its human homologue. Nature 372 425-432.

Zinker BA, Rondinone CM, Trevillyan JM, Gum RJ, Clampit JE, Waring JF, Xie N, Wilcox D, Jacobson P, Frost L, Kroeger PE, Reilly RM, Koterski S, Opgenorth TJ, Ulrich RG, Crosby S, Butler M, Murray SF, McKay RA, Bhanot S, Monia BP \& Jirousek MR 2002 PTP1B antisense oligonucleotide lowers PTP1B protein, normalizes blood glucose, and improves insulin sensitivity in diabetic mice. PNAS 99 11357-11362.

Received 16 December 2004 Accepted 21 December 2004 